\title{
National Encounters of Citizen Organizations Involved in Comprehensive Waste Management
}

\author{
Izarelly Rosillo Pantoja \\ Universidad Autónoma de Querétaro, Querétaro, Mexico
}

\begin{abstract}
The State of Jalisco, one of the main economic engines of the country, has an area of $80.137 \mathrm{~km}^{2}$, which represents $4.09 \%$ of the national territory, and a population of about 7,350,682 inhabitants, distributed in 125 municipalities. The state's population in their daily actions, generates more than 2.52 million tons of municipal solid waste (MSW) per year, to which special management waste (RME) derived from the production processes of the primary sectors are added, secondary and tertiary, whose main target has been its disposal in shared facilities ${ }^{1}$. The General Law for the Prevention and Management of Waste, establishes the possibility that the governments of the states, so agree with the Federation, take control of hazardous waste from micro generators, which generate in less than 400 kilograms per year amounts, while hazardous waste generated in households should be handled as otherwise required by municipal utilities in charge of services clean and according to the management plans in that respect are formulated and implemented. The National Encounters will allow to developing a policy and public advocacy for strengthening the truly comprehensive waste management in Mexico².
\end{abstract}

Keywords: citizen participation, political incidence, civil society organizations, management, prevention, Mexico, waste

In most Mexican towns, waste is managed precariously and without policies for minimizing it or preventing environmental damage. These towns cause serious pollution and health risks, environmental liabilities, and soil or water degradation. Many of these townships face recurring problems in matters of Comprehensive Solid Waste Management (CSWM). Since administration switches constantly from one political party to another, learning processes are interrupted, and lessons on how to improve waste management are lost. Civil society organizations that could deal with this problem are disarticulated and have not formed links with one another, which causes a waste of energy and human resources, unsystematic actions, and a lack of contact with the government.

Mexican legislation regarding the prevention and comprehensive management of waste has as its goal-the fostering of sustainable development, by preventing, recovering, and managing waste comprehensively. Mexican CSWM has the following principle as its guide:

Corresponding author: Izarelly Rosillo Pantoja, Bachelor of Laws, MA in State and Municipal Public Administration, Ph.D. candidate in law, Universidad Autónoma de Querétaro, Mexico, exercised several functions in private companies as manager and legal director, and teaches at Universidad Autónoma de Querétaro, advisor in environmental law, litigation attorney and technical secretary at Querétaro's Network for Handling Waste (REQMAR, A.C.); research fields: constitutional, notarial law, and Amparo. 1 According to the Population Census of 2010 the National Institute of Statistics and Geography (INEGI). Retrieved from http://www.inegi.org.mx/est/contenidos/proyectos/ccpv/cpv2010/Default.aspx.

2 Ministry of Environment Chile. (2014). Citizen participation. Retrieved from http://portal.mma.gob.cl/participacion-ciudadana/. 
The shared responsibility among producers, importers, exporters, traders, consumers, waste management enterprises, and municipal, state, and federal authorities is fundamental for accomplishing a comprehensive waste management that is environmentally efficient, technologically viable, and economically realizable ${ }^{3}$.

Furthermore, CSWM legislation has set out the following instruments: (1) national, state, and municipal programs for the prevention and comprehensive management of waste; (2) waste management plans with a 3R (reduce, reuse, recycle) approach; (3) social participation; and (4) the right to information.

The biggest challenge is making CSWM legislation well-known among the Mexican population—which roughly amounts to 100 million inhabitants, spread out in 2,400 townships and 32 states. The second biggest challenge is to create favorable conditions for the legislation to be complied with, bolstering informed, active, and organized citizen participation. The final goal would be a cultural change, modifying models of production, consumption, and lifestyle - all of which contribute to generating waste and environmental pollution due to their inadequate aims.

Querétaro’s Waste Management Network (REQMAR, in Spanish) has designed and organized a project for social participation - the National Encounter for Citizen Organizations Involved in Comprehensive Waste Management (hereinafter referred to as National Encounter). The project can be taken on by any state of the country. It comprises the formation of cross-sector networks for preventing and managing waste, putting together civil society actors with government institutions. This has the purpose of identifying and acknowledging successful actions performed by different organizations in matters of CSWM. REQMAR's project allows for the establishment of alliances for the strengthening of CSWM, bolstering social welfare and economic activity—since those that engage in waste management activities come mostly from underprivileged sectors. Joint actions between government and civil organizations could be the key to designing and implementing programs for an effective waste management.

The National Encounter is a triggering strategy that could foster a constructive exchange of experiences, methods, and know-how. This could be a step in achieving social empowerment, as the population targeted by 3R programs of education is trained appropriately by these programs and keep them going in spite of changes in government. With this in mind, all National Encounters should retrieve e-mails and other contact information, for participants to stay in touch. This would allow the National Encounter to work as a net of networks.

Furthermore, National Encounter must create a Citizen Agenda, which includes all roundtable proposals, obstacles found for their realization, and goals for the future suggested in all the conferences of the encounter ${ }^{4}$. The biggest challenge is achieving synergy between projects and programs, the different actors and sectors involved. Otherwise, successful actions cannot be conducted. Synergy produces more focalized efforts, as actions conducted by different organizations can sometimes focus on the same town at the same time. This amplifies the possible effects of the organizations’ activities, and enhances 3R local strategies.

\section{Goals}

One of the main goals of the National Encounter is attracting attention to the fact that all citizens generate waste, which contributes to environmental degradation and health hazards. This does not just happen locally,

\footnotetext{
${ }^{3}$ National Institute of Ecology and Climate Change. (2013). Communication and social participation in compliance to the Stockholm Convention. Retrieved from http://siscop.inecc.gob.mx/descargas/diagnos/diag_comunicacion_participacion_social. pdf.

${ }_{4}^{4}$ Retrieved from http://www.semarnat.gob.mx/eventos/anteriores/experienciasresiduos/Paginas/ArticulosyResumenes.aspx.
} 
but on a worldwide scale, as it relates to global warming and the long-distance diffusion of pollutants—such as that generated by burning garbage in open pits. The National Encounter also aims at gathering and spreading existing experiences on waste management, thus, creating a large base of information on the matter and a phonebook of those that have contributed with it. Among the encounter's other goals are the following:

(1) Enhancing organized and informed citizen participation in the prevention and managing of waste, according to national legislation in the matter;

(2) Strengthening efforts for minimizing climate change and the emission of persistent organic pollutants related to waste management;

(3) Providing technologies for reducing the emission of pollutants, environmental and health hazards related to inadequate waste management;

(4) Facilitating investment required for the adoption of said technologies, related to enhancing environmental performance, and recovering valuable waste sub-products.

\section{Methodology}

An analytical method was used for designing the model of citizen participation and political involvement, in order to determine the necessary actions and strategies, as well as the possible results of the project. Afterwards, field and documentary research was conducted, to identify the main national actors currently conducting projects related to CSWM. The author conducted a thorough search of the national register of civil society organizations. Then, the members of the relevant organizations were interviewed via e-mail. They were questioned on the goals of their organizations and their actions related to CSWM. Members of government institutions were also interviewed, as they were the ones that could inform us of successful CSWM projects conducted in each state of the country ${ }^{5}$.

An analytical method was used for selecting the participants of the National Encounter. The criteria used took into account whether the organization's proposals were innovative, whether they faced their problematics effectively, whether they had achieved a change, whether they had been successful, and whether average population had accepted their project.

A method of integration took us to identify relevant government institutions that could be interested in participating, with the purpose of strengthening ties between government and citizens. Afterwards, a committee was appointed for selecting proposals, formed by REQMAR members and federal public servers with expertise in personnel training, networking, hazardous waste, and legislation related to it ${ }^{6}$.

\section{Activities}

\section{Conferences}

Forty-six conferences were conducted. This number was higher than what had been originally intended, but the author decided that a space should be open for participants with complimentary approaches or experiences. She touched a wide array of subjects, such as the following: (1) the avoiding of waste generation; (2) the retrieving of valuable waste sub-products; (3) the management of different kinds of waste in different

\footnotetext{
${ }^{5}$ CIRIEC-España. (2014). Policy environment and civic participation. Retrieved from http://www.redalyc.org/articulo.oa?id= 17412302009.

${ }^{6}$ Cortinas de Nava, C. (2012). Ecologismo, ambientalismo, sustentabilidad (Environmentalism, environmentality, sustainability). Retrieved from http://www.cristinacortinas.net.
} 
geographic areas of the country; and (4) the managing of waste by different types of people, civil society groups, welfare organizations, schools, enterprises, and government institutions. Furthermore, the conferences were enriched with artistic activities and a message from a congressman.

\section{Articles}

Forty-six articles were received, on which each of the conferences was based upon.

\section{Posters}

The author received 29 posters.

\section{Roundtables}

Four roundtables were conducted, in which experiences and proposals were shared. All of these were integrated into the Citizen Agenda, each from different perspectives, as members came from different backgrounds and focused on separate approaches: (1) civil society and gender perspective; (2) education for a 3R culture; (3) science, technology, and the strengthening of capabilities; and (4) diminishing greenhouse gases and organic pollutants emission.

The number of participants varied in each of the four roundtables. The biggest tables gathered among 60 and 80 members, as the four put together amounted to an average of 130 people, in the two sessions they comprised.

\section{Cultural Event}

The youth group SOJA, A. C. (Active Society Youth B. C. Civil Association) was incorporated into the activities. SOJA made the National Encounter a family event. Six schools participated with cultural activities, nine music bands played, and a green market was put up, promoting sustainable consumption.

\section{Kiosks}

Twenty-five kiosks were put up, which encouraged interaction with waste management providers who promote the prevention and comprehensive management of waste. Some kiosks also offered organic low-cost products and handicrafts made with recycled waste.

\section{Results}

About 300 people attended the National Encounter. Twenty-five states were represented: Baja California, Campeche, Colima, Coahuila, Distrito Federal, Durango, Estado de México, Hidalgo, Jalisco, Michoacán, Morelos, Nuevo León, Oaxaca, Puebla, Querétaro, Quintana Roo, San Luís Potosí, Sinaloa, Sonora, Tabasco, Tamaulipas, Tlaxcala, Veracruz, Yucatán, and Zacatecas. Over 100 participants came from Querétaro.

The participants belonged to the following sectors: (1) 8\% to NGOs (non-governmental organizations); (2) $11 \%$ to the social sector (though some overlap with the NGO sector); (3) $7 \%$ to the youth sector; (4) $56 \%$ to academia; (5) 22\% to business; (6) 22\% to government; and (7) 8\% to the Counsel of Sustainable Development (the Gris Agenda) ${ }^{7}$.

The main results of the National Encounter are as follows:

(1) An electronic phonebook of those involved in the prevention and comprehensive management of waste was created and distributed;

\footnotetext{
7 SEMARNAT (Secretary of Environment and Natural Resources). (2012). Resultados y perspectivas del encuentro nacional de organizaciones involucradas en el manejo integral de residuos (Results and prospects of the national meeting of organizations involved in integrated waste management). Retrieved from http://www.semarnat.gob.mx/eventos/anteriores/experienciasresiduos/ Documents/Resultados/RESULTADOS_Y_PERSPECTIVAS.pdf.
} 
(2) The experiences gathered in articles, PowerPoint presentations, posters, and videos were made available through the web pages ${ }^{8}$;

(3) An active exchange of experiences was achieved among attendants;

(4) Main problems were defined in each of the areas the roundtables considered. The attendants' experiences were shared on the issues and the proposals made were integrated into the subjects' agendas;

(5) The issue of comprehensive waste management was made visible by posters, handicrafts, green products, and providers related to CSWM;

(6) Attention was drawn by means of a socio cultural project developed by young attendants. This project was known as "Ecological Footprint: Change Your Culture";

(7) REQMAR committed itself to creating an electronic database of the experiences related to CSWM. This database will guide the Citizen Agenda, which citizen organizations can work with. All interested parties will be able to revise the agenda before it is submitted;

(8) Two smaller National Encounters will be held. One at the "Pepena Fest" in Mexico City, on October 14-24, 2011, and one in Jalisco, with an unspecified date. Both encounters were suggested by organizations of Mexico City and Jalisco, respectively, who were interested in replicating the project. The organizations will be in charge of the organization and will focus on specific problems of their communities, delegaciones, or municipal townships. The organizations will make use of their particular areas of expertise, and the encounters will include brief conferences of local speakers and roundtables for suggesting proposals. As the National Encounter in Querétaro, these events will foster synergy among their attendants;

(9) The attendants were invited to join their local networks of waste management and build links with other interested parties.

Currently, the National Encounter has been taken on as a model in other states. The Second National Encounter will be held in Guadalajara on November 7-9, 2011 ${ }^{9}$. The Third Encounter will be held in Puebla in April $2012^{10}$.

\section{Conclusions and Recommendations}

The National Encounter was held, so a national Citizen Agenda for CSWM could be put together. The agenda included the attendants' proposals for reduction, reutilization, and recycling of waste, as well as for ways in which other citizens could be brought into the project.

The encounter was also intended to review some of the projects already in place for the prevention, separation, recollection, and management of waste. The aim was to encompass projects conducted by organizations, civil society associations, academic institutions and research centers, companies, and

\footnotetext{
${ }^{8}$ Http://www.semarnat.gob.mx/informacionambiental/encuentro/Paginas/experiencias.aspx; http://www.cristinacortinas.net.

${ }^{9}$ This Encounter helped advertise successful experiences of inter-municipal environmental management (which includes CSWM) by schools, civil society organizations, and businesses in Jalisco. It is expected that, as a result of the Encounter, efforts among different actors and sectors can be better linked. Thus, society-government-business linkages can be multiplied and CSWM can be approached at systemically. Efficient networks would share methodologies and experiences, achieving a truly successful citizen involvement. Proposals offered in roundtables were integrated into the Second Citizen Agenda. For more information go to: http://enlinea.guadalajara.gob.mx/2encuentro.

10 The Third Encounter focused on experiences of technical and financial aid from organizations of international cooperation. Aid is mainly directed at strengthening skills for the prevention and comprehensive management of waste. The projects belonged mainly to the German Gesellschaftfür Internationale Zusammenarbait (GIZ), the United States Agency for International Development (USAID), the Japanese International Cooperation Agency (JICA), the North American Commission for Environmental Cooperation (CEC), and the Border Environment Cooperative Commission (BECC).
} 
government offices. All of these groups could share their very distinct approaches and experiences, as some are based in sierras, coasts, islands, protected natural areas, rural or underprivileged urban areas. All organizations had gathered different sorts of expertise and knew how to mobilize citizens in different manners.

More and more, our model of political incidence can be reproduced in other states. People have been reaching us and sharing information in matters of CSWM. The challenge is now for citizens to empower themselves and take charge of projects for environmental sustainability. As the law states, government authorities in the matter should aid them in doing so, by offering support and providing the means for a fruitful communication among civil society organizations. By strengthening the links among civil society groups and between these groups and the government, CSWM could be applied effectively countrywide, materials could fulfill their life cycle, and the 3R approach could become a reality ${ }^{11}$.

\section{References}

CIRIEC-España. (2014). Policy environment and civic participation. Retrieved from http://www.redalyc.org/articulo.oa?id= 17412302009

Citizen Participation Guide Mexico, United States and Canada. (2013). Retrieved from http://www.ordenjuridico.gob.mx/ Publicaciones/CDs2010/CDParticipacion/pdf/DOC19.pdf

Cortinas de Nava, C. (2012). Ecologismo, ambientalismo, sustentabilidad (Environmentalism, environmentality, sustainability). Retrieved from http://www.cristinacortinas.net

Cortinas de Nava, C. (2012). Segundo encuentro nacional de organizaciones involucradas en el manejo integral de residuos (Second national meeting of organizations involved in integrated waste management). Retrieved from http://enlinea. guadalajara. gob.mx/2encuentro

Electoral Institute and Civic Participation of the State of Jalisco. (2013). Citizen participation and environment. Retrieved from http://www.iepcjalisco.org.mx/sites/default/files/unidad-editorial/publicaciones/participacion_ciudadana_y_medio_ambiente. pdf

Ministry of Environment Chile. (2014). Citizen participation. Retrieved from http://portal.mma.gob.cl/participacion-ciudadana/

National Institute of Ecology and Climate Change. (2007). The social participation in environmenta subject. Retrieved from http://www2.inecc.gob.mx/publicaciones/libros/398/simon.html

National Institute of Ecology and Climate Change. (2013). Communication and social participation in compliance to the Stockholm Convention. Retrieved from http://siscop.inecc.gob.mx/descargas/diagnos/diag_comunicacion_participacion_ social.pdf

Pantoja, I. R. (2014). Ethics and environmental justice in the State Constitutional Mexico. Mexico: Editorial Porrua Miguel Angel, pp. 145-166.

SEMARNAT (Secretary of Environment and Natural Resources). (2012). Resultados y perspectivas del encuentro nacional de organizaciones involucradas en el manejo integral de residuos (Results and prospects of the national meeting of organizations involved in integrated waste management). Retrieved from http://www.semarnat.gob.mx/ eventos/anteriores/experienciasresiduos/Documents/Resultados/RESULTADOS_Y_PERSPECTIVAS.pdf

\footnotetext{
${ }^{11}$ Pantoja, I. R. (2014). Ethics and environmental justice in the State Constitutional Mexico. Mexico: Editorial Porrua Miguel Angel, pp. 145-166.
} 